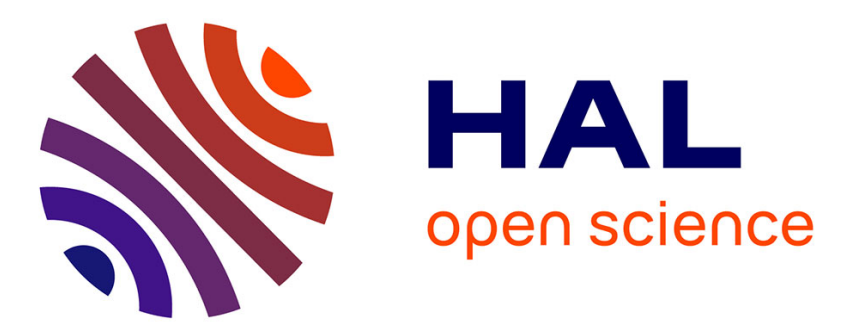

\title{
Review of Theoretical Models and Limitations of Social Commerce Adoption Literature
}

\author{
Prianka Sarker, Hatice Kizgin, Nripendra P. Rana, Yogesh Dwivedi
}

\section{To cite this version:}

Prianka Sarker, Hatice Kizgin, Nripendra P. Rana, Yogesh Dwivedi. Review of Theoretical Models and Limitations of Social Commerce Adoption Literature. 18th Conference on e-Business, e-Services and e-Society (I3E), Sep 2019, Trondheim, Norway. pp.3-12, 10.1007/978-3-030-29374-1_1 . hal02510095

\section{HAL Id: hal-02510095 \\ https://hal.inria.fr/hal-02510095}

Submitted on 17 Mar 2020

HAL is a multi-disciplinary open access archive for the deposit and dissemination of scientific research documents, whether they are published or not. The documents may come from teaching and research institutions in France or abroad, or from public or private research centers.
L'archive ouverte pluridisciplinaire HAL, est destinée au dépôt et à la diffusion de documents scientifiques de niveau recherche, publiés ou non, émanant des établissements d'enseignement et de recherche français ou étrangers, des laboratoires publics ou privés. 


\title{
Review of Theoretical Models and Limitations of Social Commerce Adoption Literature
}

\author{
Prianka Sarker ${ }^{1}$, Hatice Kizgin ${ }^{2}$, Nripendra P. Rana ${ }^{3}$ Yogesh K. Dwivedi ${ }^{4}$ \\ ${ }^{1}$ Emerging Markets Research Centre (EMaRC), School of Management, Swansea University \\ Bay Campus, Swansea, SA1 8EN, UK \\ \{937449@swansea.ac.uk\} \\ ${ }^{2}$ Emerging Markets Research Centre (EMaRC), School of Management, Swansea University \\ Bay Campus, Swansea, SA1 8EN, UK \\ \{Hatice.Kizgin@Swansea.ac.uk\} \\ ${ }^{3}$ Emerging Markets Research Centre (EMaRC), School of Management, Swansea University \\ Bay Campus, Swansea, SA1 8EN, UK \\ \{n.p.rana@swansea.ac.uk\} \\ ${ }^{4}$ Emerging Markets Research Centre (EMaRC), School of Management, Swansea University \\ Bay Campus, Swansea, SA1 8EN, UK \\ \{ykdwivedi@gmail.com;y.k.dwivedi@swansea.ac.uk\}
}

\begin{abstract}
Social commerce is emerging as an important platform in e-commerce. It brings people to the comfort zone to buying and selling product that they cannot reach physically. The purpose of this research is to review the empirical research on social commerce published between 2012 to 2019. The paper mainly reviews the theories and models used in this area and limitations acknowledged by studies in social commerce area. The findings indicated that TAM, social support theory and S-O-R model are some of the most frequently used models. Also, use of biased sample, limited factors and cross-sectional studies are some of the most common limitations used across majority of studies.
\end{abstract}

Keywords: Social commerce, Literature review, TAM

\section{Introduction}

Social commerce is a new version of e-commerce that contains using social media that supports user contributions and social interactions to assist in the buying and selling of products and services online [1]. Yahoo is the first organisation who introduce social commerce concept in 2005. Following Yahoo; Facebook, Google, Instagram and many other social platforms adopted this concept and enhancing the businesses. Berkowitz [2] said that social commerce is how markets leverage social media to influence consumers' shopping behaviour, spanning product consideration, purchase intent, the transaction itself and post-transaction advocacy and retention. Social commerce is the digital presence of marketers, and it has been used depending on marketers' goals, interest and strategy. Carton [3] states that social commerce is a platform for buying and selling product through interaction between people. Social commerce is a potential online scale, reach and ease of sharing and connecting people. Social commerce brings people to the comfort zone to buying and selling a product that they cannot reach physically. On one side, it is fulfilling consumer's desire and another side it is developing the businesses. Increasing the demand and importance of social commerce, several studies have been conducted last few years in different aspects. For example, consumer behaviours on social commerce, consumer intention to buy, social commerce adoption, impulsive buying behaviour on social commerce, different factors that influence social commerce, social commerce online features. Several researchers have found different theories and model for developing social commerce. This paper attempts to 
review the past journal papers related to social commerce published between 2012 to 2019 and specifically empirical studies by nature. This study also discussed previous literature review papers to reduce the similarity of the research. For example, Busalim [4] conducted a systematic review of social commerce to explore the term of social commerce by reviewing the studies that related to social commerce published from 2010 to 2015. This study highlighted the understanding of customers' needs that influence the customer to stick with the same seller. Moreover, the study found that acquisition and retention are key success factors that need more investigation. Most of the studies focused on the intention of customers to buy in social commerce sites and transactional behaviour. Another systemic literature review has conducted by synthesising 407 papers from academic publications between 2006 and 2017. This study focused to reveal current social commerce researches, different research methods that used in social commerce, and future areas for social commerce researches [5]. Zhang [6] did the literature review conducted a systematic review of consumer behaviour on social commerce sites. This study particularly discussed theories and identify essential research methods. More importantly, this study draws upon the stimulus-organism-response model and the five-stage consumer decision-making process to propose an integrative framework for a holistic understanding of consumer behaviour. Hajli [7] studied on the framework of social commerce adoption. The findings from the model indicate that forums and communities, rating and reviews and referrals and recommendations are the primary constructs of social commerce adoption model. It was also found that trust is the on-going problem of e-commerce, and it can be developed through social commerce constructs. Altinisik and Yildirim [8] conducted a literature review on consumer adoption of social commerce and founded that social support theory, trust transfer theory, TAM and S-O-R model are used in five studies. China developed the highest number of studies, which is 14 in the context of social commerce adoption. The study also found that Social presence is the most frequent social factors where trust towards the website is the most frequent personal factor.

However, there is a lack in the literature review as regards of identifying most frequent used models, theories and Limitations in social commerce researches. Considering the discussion presented above, this study focuses mainly on two questions:

RQ1: what are the models/theories were used in past social commerce studies? RQ2: What are the most frequent Limitations that has mentioned in past studies? To finding those questions, this paper undertakes analysis and synthesis of existing research related to social commerce adoption. To achieve the aim, the remaining part of the paper is structured as followed: section two will describe the literature search and analysis approach. Section three will be described by different models, theories that have been found from previous literature. Section four discuss the identified limitations.

\section{Systematic Literature Approach}

This paper used the following keyword to find relevant article using google scholar, Scopus, ScienceDirect, scholar database: "social commerce adoption" OR "consumer adoption of social commerce" OR "Consumers' behaviour on social commerce" OR "using intention of social commerce" OR "Influence Factors of social commerce" in order to identify the relevant article. The keyword search returned 110 papers. 25 papers were not relevant with this study and 16 papers were not accessible. However, we focused on 69 studies that directly relevant to individual consumer adoption of social commerce, consumer intention to use in social commerce and the factor that influence social commerce adoption.

3. Frequently used Theories/Model in the area of social commerce

Scholarly work has found social commerce adoption using various models and theories. The table below summarizes most frequent found models and theories. 
Table 1: Models/Theories

\begin{tabular}{|c|c|c|}
\hline Model/Theory & Freq & Citations \\
\hline $\begin{array}{l}\text { Technology } \\
\text { model (TAM) }\end{array}$ & 17 & $\begin{array}{l}\text { Biucky et al. [9]; Cabanillas and Santos [10]; Chung et al. } \\
\text { [11]; Dwairi et al. [12]; Gibreel et al. [13]; Gutama and } \\
\text { Intani [14]; Hajli [15];Hajli [16]; Huang and Benyoucef [17] } \\
\text { Jiang et al. [18]; Kim et al.[19]; Shin,[20]; Shen [21]; } \\
\text { Srinivasan [22]; Liang [22]; Wang and Yu [24]. }\end{array}$ \\
\hline Social support theory & 11 & $\begin{array}{l}\text { Chen and Shen [25]; Hajli [26, 27] Hajli et al. [28]; Li [29]; } \\
\text { Liang and Turban [30]; Makmor and Alam [31]; Molinillo } \\
\text { et al. [32]; Shanmugam et al. [33]; Sheikh et al. [34]; Tajvidi } \\
\text { et al. [35]. }\end{array}$ \\
\hline $\begin{array}{l}\text { Stimulus-Organism } \\
\text { Response (S-O-R) model }\end{array}$ & 7 & $\begin{array}{l}\mathrm{Li}[29] \text {; Molinillo et al. [32]; Liu et al. [36]; Kim [37]; Wu } \\
\text { and Li [38]; Xiang et al. [39]; Zhang et al. [40]. }\end{array}$ \\
\hline $\begin{array}{l}\text { Theory of Planned } \\
\text { Behaviour }\end{array}$ & 6 & $\begin{array}{l}\text { ef [17]; Shin, [20]. Lu et al. } \\
\text { Wu [47]. }\end{array}$ \\
\hline Trust transfer Theory & 4 & Chen [25], Bai et al. [44]; $\mathrm{Ng}$ [45]; Shi and Chow [46]. \\
\hline Relationship Quality theory & 4 & $\begin{array}{l}\text { Hajli [19]; Tajvidi et al. [35]; Zhang et al. [47]; Lin et al. } \\
\text { [48]. }\end{array}$ \\
\hline ocial exchange theory & 4 & Li [29]; Molinillo et al. [32]; Yang et al. [49]; Lin et al. [50]. \\
\hline $\begin{array}{l}\text { Theory of Reasoned Action } \\
\text { (TRA) }\end{array}$ & 4 & $\begin{array}{l}\text { Huang and Benyoucef [17]; Kim and Park [58]; Teh et al. } \\
\text { [59]; Akman and Mishra [60]. }\end{array}$ \\
\hline $\begin{array}{lll}\text { UTAUT } & \text { (Theory } & \text { of } \\
\text { acceptance and use } & \text { of } \\
\text { technology) } & & \\
\end{array}$ & 3 & $\begin{array}{l}\text { Nadeem et al. [51]. Yahia et al. [52]; Gatautis and } \\
\text { Medziausiene [53]. }\end{array}$ \\
\hline Social Learning Theory & 3 & Chen $[55,56] ;$ Li et al. [57], \\
\hline ocial identity theory & 2 & 1. [42]; Wang [61]. \\
\hline \multicolumn{3}{|c|}{$\begin{array}{l}\text { Models and theories with only one occurrence: Commitment-Trust Theory, Chen and Shen } \\
\text { [10]; SCAM model, Hajli [15]; Holistic Theory, Liu et al.[40]; Social presence theory, Lu et al. } \\
\text { [41]; Consumer behavior theory, Bai et al. [44]; EWOM model, Noori et al. [54]; Motivation } \\
\text { theory, Yang et al. [49]; Communication Privacy Management (CPM) theory, Sharma and } \\
\text { Crossler [62]; Keno model, Choi and Kim [63]; Push-Pull-mooring model, Li and Ku [64];An } \\
\text { integrated gratifications and motivational model (IGMM), Osatuyi and Qin [65]; Complexity } \\
\text { theory, Pappas [66]; Utilitarian and hedonic motivation theory, Mikalef [67]. }\end{array}$} \\
\hline
\end{tabular}

In discussion section we particularly picked up most significant and relevant articles to discuss. Technology acceptance model best known as TAM is the most used model in social commerce adoption. TAM has been adopted, adapted and extended in many various contexts. TAM has been used in 17 studies in social commerce context. TAM used to examine user preferences of social features on social commerce websites, drivers of social commerce, evaluating different factors of social commerce, Social interaction-based consumer decision-making model, Effects of antecedents of collectivism on consumers' intention to use social commerce, Social commerce adoption and the effects of perceived risk on social commerce adoption [9,10,12-15,18-24]. Chung [11] used TAM alongside with commodity theory, psychological reactance theory, naive economic theory to utilise consumers' impulsive buying behaviour of restaurant products in social commerce context. TAM alongside with theory of planned behaviour was used in multiple studies. Hajli [16] evaluate social 
commerce constructs and consumer's intention to purchase. Huang and Benyoucef [17] has utilised TAM model along with TRA (theory of reasoned action) and TPB (The theory of planned behaviour). Shin [20] explore user experience in the adaptation of social commerce.

Social support theory is another popular theory in social commerce context. Social support theory has used in 11 studies to evaluate different contexts of social commerce adoption. Chen and Shen, [25] explore consumers' decision making in social commerce context. Hajli [27] explore social support on relationship quality using social support theory. Li, [29] explored social commerce constructs that influence social shopping intention using social support theory and SO-R model. Makmor and Alam [31] evaluate the consumers' attitude towards adaptation of social commerce. Molinillo et al. [32] explore social commerce intention model to adaptation of social commerce. Sheikh et al. [34] explore the acceptance of social commerce in the context of Saudi Arabia. Stimulus-organism-response (S-O-R) model has been used in seven studies in social commerce context. Impulsive buying behaviour, customer motivation to participate in social commerce, consumer behaviour, marketing mix, and consumer value and consumer loyalty has used S-O- R model to examination those studies [36-40]. There are some other theories such as trust transfer theory, Relationship quality theory, Theory of Reasoned Action (TRA) and Social exchange theory has frequently used in the context of social commerce adoption. However, UTAUT, Social learning theory and social exchange theory occurs in three studies in social commerce context. There are some other theory and model such as CommitmentTrust Theory, SCAM, Holistic Theory, Social presence theory, Motivation theory, Communication Privacy Management (CPM) theory, Complexity theory, Utilitarian and hedonic motivation theory, Push-Pull-mooring model occurs in single studies where some models/theories has combined with other models/theories and some used along. However, those models/theories have contribution of exploration in different studies and played a played a vital role in several studies.

\section{Research Limitations}

Table 2 provides a summary of most frequent identified limitations in studies on social commerce adoption. The review finds sampling, single subjects are most frequent limitation in several studies. Furthermore, Limited factors, Cross sectional studies, use of specific model, method, and tools are the main limitations.

Table 2: Frequently mentioned Limitations

\begin{tabular}{|l|l|l|l|}
\hline Limitations & Freq & Explanation & \multicolumn{1}{|c|}{ Citations } \\
\hline $\begin{array}{l}\text { Single } \\
\text { subject/bias } \\
\text { ed sample }\end{array}$ & 23 & $\begin{array}{l}\text { Sample based } \\
\text { on only one or } \\
\text { limited, } \\
\text { community, } \\
\text { culture, } \\
\text { country, } \\
\text { parson or age } \\
\text { group }\end{array}$ & $\begin{array}{l}\text { Dwairi [12]; Gibreel et al. [13]; Huang and } \\
\text { Benyoucef [17]; jiang [18]; Srinivasan [22]; } \\
\text { Wang et al. [24]; Chen and Shen [25]; Hajli [28]; } \\
\text { Molinillo et al. [32]; Sheikh et al.[34]; Tajvidi et } \\
\text { al. [35]; Wu and Li [38]; Xiang et al. [39]; Zhang } \\
\text { et al. [40]; Farivar [42]; Lin et al. [43]; Bai et al. } \\
\text { [44]; Ng [45]; Zhang et al. [47]; Yang et al. [49 ]; } \\
\text { Akman and Mishra [60]; Pappas et al. [66]; } \\
\text { Braojos et al. [68] }\end{array}$ \\
\hline $\begin{array}{l}\text { Limited } \\
\text { factors }\end{array}$ & 15 & $\begin{array}{l}\text { Counted } \\
\text { number } \\
\text { external } \\
\text { constructs }\end{array}$ & $\begin{array}{l}\text { Biucky et al. [9]; Chung [11]; Wang [24]; Chen } \\
\text { and Shen [25]; Liu et al.[36]; Wu and Li [38]; } \\
\text { Xiang [39]; Zhang et al.[40]; Farivar et al. [42]; }\end{array}$ \\
\hline
\end{tabular}




\begin{tabular}{|l|l|l|l|}
\hline & & & $\begin{array}{l}\text { Bai et al. [44]; Ng [45]; Shi and Chow [46]; Zhang } \\
\text { et al. [47]; Yang et al. [49]; Pappas et al. [66] }\end{array}$ \\
\hline Platform & 11 & $\begin{array}{l}\text { Sample based } \\
\text { on specific } \\
\text { SNS platform }\end{array}$ & $\begin{array}{l}\text { Gibreel et al. [13]; Huang and Benyoucef [17]; } \\
\text { Hajli [27,28]; Sheikh et al.[34] Wu and Li [38]; } \\
\text { Bai et al. [44]; Noori et al. [54]; Yahia et al. [52]; } \\
\text { Gatautis and Medziausiene [53]; Braojos et al. [68] }\end{array}$ \\
\hline $\begin{array}{l}\text { Cross- } \\
\text { sectional } \\
\text { study }\end{array}$ & 8 & $\begin{array}{l}\text { one-time } \\
\text { cross- } \\
\text { sectional } \\
\text { study }\end{array}$ & $\begin{array}{l}\text { Cabanillas and Santos [10]; Chung et al. [11]; } \\
\text { Huang and Benyoucef [17]; Kim et al. [19]; Lu et } \\
\text { al. [41]; Shi et al. [46]; Noori et al. [54]; Akman } \\
\text { and Mishra [60]. }\end{array}$ \\
\hline $\begin{array}{l}\text { Using } \\
\text { specific } \\
\text { model/ } \\
\text { theory }\end{array}$ & 6 & $\begin{array}{l}\text { Specific type } \\
\text { of model and } \\
\text { theory }\end{array}$ & $\begin{array}{l}\text { Sheikh et al. [34]; Liu [36]; Wu and Li [38]; Xiang } \\
\text { et al. [39]; Farivar et al. [42]; Wang et al. [61] }\end{array}$ \\
\hline $\begin{array}{l}\text { Limited } \\
\text { sample size }\end{array}$ & 6 & $\begin{array}{l}\text { Small sample } \\
\text { size }\end{array}$ & $\begin{array}{l}\text { Cabanillas and Santos [10]; Gibreel et al. [13]; } \\
\text { Molinillo et al. [32]; Zhang et al. [40]; Gatautis } \\
\text { and Medziausiene [53]; Akman and Mishra [60] }\end{array}$ \\
\hline
\end{tabular}

Table 2 showing the most frequent limitation that has occurs in different studies during their studies. The table showing that 23 studies found a single subject and the biased sample is the most frequent limitation. The sample of the study based on a single community, culture, country, person age group. The major amount of study has been conducted in China, where researchers collected the data as chinses cultural perspectives using Chinese social commerce platform such as WeChat, RenRen, Weibo etc. However, the finding does not generalise the other part of the world. The researchers suggested collecting the more diversified sample to adding more value and discard the bias. In this analysis, it has been founded that most sampling has collected from students and the age group from 18 to 35 . However, few researchers suggested to collect the sample from an older generation to gain their perspective towards social commerce also, can be compared with the younger generation and older generation to find what exactly which generation demand from social commerce. The second highest mentioned limitation is limited factors. Cross-sectional studies have been founded in eight studies. It is described that the sample is collected from a single point of time. Moreover, most of the studies employed survey-based data collection with self-reported questionnaires that limit the overall perspective of the participant.

Moreover, researcher mostly used five and seven Likert scale to measure the data. Furthermore, the majority of studies have employed a quantitative approach [5]. However, the researcher suggested to employed qualitative methods for collecting the data. Such as Observation, interviews, focus group discussion session could be employed for future research, for quantitative approach researcher suggested to employed longitudinal studies which are the same data sources that repeatedly use for an extended period of time. The platform is an important aspect of social commerce studies. However, the researcher found that the perspective of one social commerce platform users cannot provide generalised other social commerce platform user perspective. As an example, WeChat only uses in China, so the collected data from WeChat only shows China's social commerce perspective. However, the researcher suggested that employees' multiple platforms collect the data and users who use different social commerce platform. This will enhance the broad understanding of various social commerce platform. This has been founded that TAM, social commerce theory, S-O-R model are used in most of the studies which have limited the findings of social commerce area. However, there are some model and theory that has used in fewer studies could be employed in future research. Such as theory of planned behaviour is used in six studies whereas UTAUT, Trust transfer theory employed in limited studies. However, the researcher suggested to employees those underrated theories and model for future 
research. This may produce a new understanding of the social commerce area. Few researchers suggested to employ larger sampling due to more understanding of social commerce context. There are some other, such as using different tools or techniques to analysis sampling. Such as SEM-PLS has used most frequently. Where the SPSS tool has mostly employed to measure that data, some of the studies applied Vikor, ANOVA, AMOS for analysis of the data. However, the researcher suggested using some other useful tools such as LISREL, LAS for measure future data.

\section{Conclusion}

This paper conducted a review of past literature on the area of social commerce in particular consumer adoption of social commerce. From this review, the study found that TAM is the most useful and most used model for this specific area. Moreover, S-O-R, Social support theory are equally important to investigate any research. Study Also Found some other theories that were used with some core model and theory and those are also an essential aspect of social commerce adoption. In most of the study found that data collection, sample size, specific culture and country are some frequent limitation. Moreover, using a single method, factor, tool and Technique create the limitation in the study. In terms of the limitation of this study, we analyse the journal paper studied from 2012 to 2019. Also, this paper did not include any books and conference papers. Furthermore, this research did not include any methodology analysis and future research analysis. The motivation of this study is to unfold the model/theories that have used most frequently in different studies. However, some model/theories are overlooking and has used one or two studies. Highlighting those underrated theories/model may discover different findings of social commerce. This study also highlighted the limitations. Future researches should reduce most of the limitations in social commerce studies, which may provide more information about the adoption of social commerce.

\section{References}

1. Shen, J., and Eder, L. B. (2011). An examination of factors associated with user acceptance of social shopping websites. International Journal of Technology and Human Interaction (IJTHI), 7(1), 19-36.

2. Berkowitz, D. (2011). Social Commerce Defined. [online] Heidi Cohen. Available at: https:/heidicohen.com/social-commerce-defined/ [Accessed 21 Feb. 2019].

3. Carton, S. (2011). Social Commerce Defined. [online] Heidi Cohen. Available at: https://heidicohen.com/social-commerce-defined/ [Accessed 21 Feb. 2019].

4. Busalim, A. H. (2016). Understanding social commerce: A systematic literature review and directions for further research. International Journal of Information Management, 36(6), 1075-1088.

5. Han, H., Xu, H., and Chen, H. (2018). Social commerce: A systematic review and data synthesis. Electronic Commerce Research and Applications, 30, 38-50.

6. Zhang, K. Z., and Benyoucef, M. (2016). Consumer behavior in social commerce: A literature review. Decision Support Systems, 86, 95-108.

7. Hajli, M. (2013). A research framework for social commerce adoption. Information Management and Computer Security, 21(3), 144-154.

8. Altinisik and Yildirim. (2017). Consumers' adoption of social commerce: a systematic literature review. Mugla Journal of Science and Technology. 3 (2), 131-137. 
9. Biucky, S. T., and Harandi, S. R. (2017). The effects of perceived risk on social commerce adoption based on TAM Model. International Journal of Electronic Commerce Studies, 8(2), 173-196.

10. Liébana-Cabanillas, F., and Alonso-Dos-Santos, M. (2017). Factors that determine the adoption of Facebook commerce: The moderating effect of age. Journal of Engineering and Technology Management, 44, 1-18.

11. Chung, N., Song, H. G., and Lee, H. (2017). Consumers' impulsive buying behavior of restaurant products in social commerce. International Journal of Contemporary Hospitality Management, 29(2), 709-731.

12. Al-Dwairi, R. (2017). Social commerce adoption among Jordanian youth: empirical study. International Journal of Business Information Systems, 26(3), 277-296.

13. Gibreel, O., AlOtaibi, D. A., and Altmann, J. (2018). Social commerce development in emerging markets. Electronic Commerce Research and Applications, 27, 152-162.

14. Gutama, W. A., and Intani, A. P. D. (2017). Consumer acceptance towards online grocery shopping in Malang, east java, Indonesia. Agricultural Socio-Economics Journal, 17(1), 23.

15. Hajli, M. (2012). An integrated model for e-commerce adoption at the customer level with the impact of social commerce. International Journal of Information Science and Management (IJISM), 77-97.

16. Hajli, N. (2015). Social commerce constructs and consumer's intention to buy. International Journal of Information Management, 35(2), 183-191.

17. Huang, Z., and Benyoucef, M. (2017). The effects of social commerce design on consumer purchase decision-making: an empirical study. Electronic Commerce Research and Applications, 25, 40-58.

18. Jiang, G., Ma, F., Shang, J., and Chau, P. Y. (2014). Evolution of knowledge sharing behavior in social commerce: an agent-based computational approach. Information Sciences, 278, 250-266.

19. Kim, S., Noh, M. J., and Lee, K. T. (2012). Effects of antecedents of collectivism on consumers' intention to use social commerce. Journal of Applied Sciences, 12(12), $1265-1273$.

20. Shin, D. H. (2013). User experience in social commerce: in friends we trust. Behaviour and information technology, 32(1), 52-67.

21. Shen, J. (2012). Social comparison, social presence, and enjoyment in the acceptance of social shopping websites. Journal of Electronic Commerce Research, 13(3), 198.

22. Srinivasan, R. (2015). Exploring the impact of social norms and online shopping anxiety in the adoption of online apparel shopping by Indian consumers. Journal of Internet Commerce, 14(2), 177-199.

23. Liang, T. P., Ho, Y. T., Li, Y. W., and Turban, E. (2011). What drives social commerce: The role of social support and relationship quality. International Journal of Electronic Commerce, 16(2), 69-90.

24. Wang, Y., and Yu, C. (2017). Social interaction-based consumer decision-making model in social commerce: The role of word of mouth and observational learning. International Journal of Information Management, 37(3), 179-189.

25. Chen, J., and Shen, X. L. (2015). Consumers' decisions in social commerce context: An empirical investigation. Decision Support Systems, 79, 55-64.

26. Hajli, M. (2013). A research framework for social commerce adoption. Information Management and Computer Security, 21(3), 144-154.

27. Hajli, M. N. (2014). The role of social support on relationship quality and social commerce. Technological Forecasting and Social Change, 87, 17-27. 
28. Hajli, N., Shanmugam, M., Powell, P., and Love, P. E. (2015). A study on the continuance participation in on-line communities with social commerce perspective. Technological Forecasting and Social Change, 96, 232-241.

29. Li, C. Y. (2017). How social commerce constructs influence customers' social shopping intention? An empirical study of a social commerce website. Technological Forecasting and Social Change.

30. Liang, T. P., and Turban, E. (2011). Introduction to the special issue social commerce: a research framework for social commerce. International Journal of electronic commerce, 16(2), 5-14.

31. Makmor, N. B., and Alam, S. S. (2017). Attitude towards Social Commerce: A Conceptual Model Regarding Consumer Purchase Intention and its Determinants. International Journal of Economic Research, 14(15), 431-441.

32. Molinillo, S., Liébana-Cabanillas, F., and Anaya-Sánchez, R. (2018). A social commerce intention model for traditional e-commerce sites. Journal of theoretical and applied electronic commerce research, 13(2), 80-93.

33. Shanmugam, M., Sun, S., Amidi, A., Khani, F., and Khani, F. (2016). The applications of social commerce constructs. International Journal of Information Management, 36(3), 425-432.

34. Sheikh, Z., Islam, T., Rana, S., Hameed, Z., and Saeed, U. (2017). Acceptance of social commerce framework in Saudi Arabia. Telematics and Informatics, 34(8), 1693-1708.

35. Tajvidi, M., Wang, Y., Hajli, N., and Love, P. E. (2017). Brand value Co-creation in social commerce: The role of interactivity, social support, and relationship quality. Computers in Human Behavior.

36. Liu, H., Chu, H., Huang, Q., and Chen, X. (2016). Enhancing the flow experience of consumers in China through interpersonal interaction in social commerce. Computers in Human Behavior, 58, 306-314.

37. Kim, J. B. (2015). The mediating role of presence on consumer intention to participate in a social commerce site. Journal of Internet commerce, 14(4), 425-454.

38. $\mathrm{Wu}, \mathrm{Y}$. L., and Li, E. Y. (2018). Marketing mix, customer value, and customer loyalty in social commerce: A stimulus-organism-response perspective. Internet Research, 28(1), 74-104.

39. Xiang, L., Zheng, X., Lee, M. K., and Zhao, D. (2016). Exploring consumers' impulse buying behavior on social commerce platform: The role of parasocial interaction. International Journal of Information Management, 36(3), 333-347.

40. Zhang, H., Lu, Y., Gupta, S., and Zhao, L. (2014). What motivates customers to participate in social commerce? The impact of technological environments and virtual customer experiences. Information and Management, 51(8), 1017-1030.

41. Lu, B., Fan, W., and Zhou, M. (2016). Social presence, trust, and social commerce purchase intention: An empirical research. Computers in Human Behavior, 56, 225237.

42. Farivar, S., Turel, O., and Yuan, Y. (2018). Skewing users' rational risk considerations in social commerce: An empirical examination of the role of social identification. Information and Management, 55(8), 1038-1048.

43. Lin, C. S., and Wu, S. (2015). Exploring antecedents of online group-buying: Social commerce perspective. Human Systems Management, 34(2), 133-147.

44. Bai, Y., Yao, Z., and Dou, Y. F. (2015). Effect of social commerce factors on user purchase behavior: An empirical investigation from renren.com. International Journal of Information Management, 35(5), 538-550.

45. Ng, C. S. P. (2013). Intention to purchase on social commerce websites across cultures: A cross-regional study. Information and management, 50(8), 609-620. 
46. Shi, S., and Chow, W. S. (2015). Trust development and transfer in social commerce: prior experience as moderator. Industrial Management and Data Systems, 115(7), 1182-1203.

47. Zhang, K. Z., Benyoucef, M., and Zhao, S. J. (2016). Building brand loyalty in social commerce: The case of brand microblogs. Electronic Commerce Research and Applications, 15, 14-25.

48. Lin, J., Yan, Y., and Chen, S. (2017). Understanding the impact of social commerce website technical features on repurchase intention: a Chinese guanxi perspective. Journal of Electronic Commerce Research, 18(3), 225.

49. Yang, J., Sia, C. L., Liu, L., and Chen, H. (2016). Sellers versus buyers: differences in user information sharing on social commerce sites. Information Technology and People, 29(2), 444-470.

50. Lin, J., Luo, Z., Cheng, X., and Li, L. (2019). Understanding the interplay of social commerce affordances and swift guanxi: An empirical study. Information and Management, 56(2), 213-224.

51. Nadeem, W., Juntunen, M., and Juntunen, J. (2017). Consumer segments in social commerce: A latent class approach. Journal of Consumer Behaviour, 16(3), 279-292.

52. Yahia, I. B., Al-Neama, N., and Kerbache, L. (2018). Investigating the drivers for social commerce in social media platforms: Importance of trust, social support and the platform perceived usage. Journal of Retailing and Consumer Services, 41, 11-19.

53. Gatautis, R., and Medziausiene, A. (2014). Factors affecting social commerce acceptance in Lithuania. Procedia-Social and Behavioral Sciences, 110, 1235-1242.

54. Noori, A. S., Hashim, K. F., and Yusof, S. A. M. (2016). The Conceptual Relation of Electronic Word-of-mouth, Commitment and Trust in Influencing Continuous Usage of Social Commerce. International Review of Management and Marketing, 6(7S), 226230.

55. Chen, A., Lu, Y., and Wang, B. (2017). Customers' purchase decision-making process in social commerce: a social learning perspective. International Journal of Information Management, 37(6), 627-638.

56. Chen, A., Lu, Y., and Gupta, S. (2017). Enhancing the decision quality through learning from the social commerce components. Journal of Global Information Management (JGIM), 25(1), 66-91.

57. Li, Q., Liang, N., and Li, E. Y. (2018). Does friendship quality matter in social commerce? An experimental study of its effect on purchase intention. Electronic Commerce Research, 18(4), 693-717.

58. Kim, S., and Park, H. (2013). Effects of various characteristics of social commerce (scommerce) on consumers' trust and trust performance. International Journal of Information Management, 33(2), 318-332.

59. Teh, P. L., Ahmed, P. K., and Tayi, G. K. (2015). Generation-Y shopping: the impact of network externalities and trust on adoption of social commerce. International Journal of Electronic Business, 12(2), 117-141.

60. Akman, I., and Mishra, A. (2017). Factors influencing consumer intention in social commerce adoption. Information Technology and People, 30(2), 356-370.

61. Wang, T., Yeh, R. K. J., and Yen, D. C. (2015). Influence of customer identification on online usage and purchasing behaviors in social commerce. International Journal of Human-Computer Interaction, 31(11), 805-814.

62. Sharma, S., and Crossler, R. E. (2014). Disclosing too much? Situational factors affecting information disclosure in social commerce environment. Electronic Commerce Research and Applications, 13(5), 305-319.

63. Choi, S. B., and Kim, J. M. (2018). A comparative analysis of electronic service quality in the online open market and social commerce: the case of Korean young adults. Service Business, 1-31. 
64. Li, C. Y., and Ku, Y. C. (2018). The power of a thumbs-up: Will e-commerce switch to social commerce. Information and Management, 55(3), 340-357.

65. Osatuyi, B., and Qin, H. (2018). How vital is the role of effect on post-adoption behaviors? An examination of social commerce users. International Journal of Information Management, 40, 175-185.

66. Pappas, I. O., Kourouthanassis, P. E., Giannakos, M. N., and Chrissikopoulos, V. (2016). Explaining online shopping behavior with fsQCA: The role of cognitive and affective perceptions. Journal of Business Research, 69(2), 794-803.

67. Mikalef, P., Giannakos, M., and Pateli, A. (2013). Shopping and word-of-mouth intentions on social media. Journal of theoretical and applied electronic commerce research, 8(1), 17-34.

68. Braojos, J., Benitez, J., and Llorens, J. (2019). How do social commerce-IT capabilities influence firm performance? Theory and empirical evidence. Information and Management, 56(2), 155-171.

69. Sheikh, Z., Islam, T., Rana, S., Hameed, Z., and Saeed, U. (2017). Acceptance of social commerce framework in Saudi Arabia. Telematics and Informatics, 34(8), 1693-1708. 